\title{
Above- and Belowground Microclimate of Grow Tubes in an Organic Mulch-incorporated, Raised Bed System for Blueberry
}

\author{
Julie M. Tarara ${ }^{1}$ \\ USDA-ARS, Horticultural Crops Research Unit, 24106 N. Bunn Road, \\ Prosser, WA 99350
}

\section{Bernardo Chaves \\ Washington State University Irrigated Agriculture Research and Extension Center, 24106 N. Bunn Road, Prosser, WA 99350}

\author{
Bernadine C. Strik \\ Department of Horticulture, Oregon State University, Corvallis, OR 97330
}

Additional index words. humidity, solar radiation, temperature, tree shelter, Vaccinium corymbosum, vapor pressure deficit

\begin{abstract}
Grow tubes are well established in forestry and are gaining attention in establishing some woody perennial crops. To date, microclimate descriptions have addressed the aboveground environment, but a mulched raised bed system with organic mulch-incorporated soil requires both the above- and belowground microclimate to be quantified. We measured the microclimate of commercially used, non-ventilated translucent and non-ventilated opaque grow tubes in a model crop of blueberry (Vaccinium corymbosum L.) grown on sawdust-mulch-covered raised beds formed from sawdustincorporated tilled soil. The differences in air temperature between tubes and ambient were consistent with those reported in the literature. Air temperature in translucent tubes was up to $19.7^{\circ} \mathrm{C}$ higher than ambient. Differences in vapor pressure deficit were largely a function of differences in air temperature between tubes and ambient rather than actual vapor pressure. Stem temperatures were highest outside of the tubes as a result of radiation load. The surface temperature of ambient sawdust mulch (maximum $53{ }^{\circ} \mathrm{C}$ ) was up to $14{ }^{\circ} \mathrm{C}$ above that in the translucent tube and $20{ }^{\circ} \mathrm{C}$ above that in the opaque tube. The largest gradients in the bed system were between the loose dry mulch and the soil-mulch interface. The presence of a grow tube did not influence soil temperature or its daily amplitude at $15 \mathrm{~cm}$ below the surface- the native tilled soil. Temperatures associated with the opaque tubes were between ambient and those in the translucent tubes. The temperature data indicate that both opaque and translucent unventilated grow tubes should influence shoot and crown growth but may have little influence on root growth in this shallow-rooted plant.
\end{abstract}

The use of protective tubes in forestry is a common and now longstanding practice for establishing tree seedlings, described first in the peer-reviewed literature in the oft-cited work of Tuley $(1983,1985)$. Referred to in forestry as tree shelters, the tubes were developed primarily to prevent herbivory (i.e., deer and rabbit browsing) and to facilitate weed management. Tubes may be left on the tree for multiple years during forest establishment or for shorter periods in tree seedling nurseries. Their influence on tree growth

\footnotetext{
Received for publication 21 Aug. 2013. Accepted for publication 20 Sept. 2013.

We acknowledge and are grateful for Gil Buller's technical support, partial funding provided by the Oregon Blueberry Commission, and the valuable contributions of our grower collaborator (PanAmerican Berry Growers, Salem, OR).

${ }^{1}$ To whom reprint requests should be addressed; e-mail julie.tarara@ars.usda.gov.
}

horticultural literature (e.g., Kjelgren, 1994; Kjelgren et al., 1997) including in the trade press (e.g., Due, 1990). In the agricultural context, grow tubes are used for one growing season but occasionally are left in place over the winter to protect the plants from the initial herbicide application the next spring. Agricultural grow tubes also are shorter than those typically used in open-field forestry (e.g., 0.6 to $0.8 \mathrm{~m}$ vs. 1.2 to greater than $2 \mathrm{~m}$ ), although they are comparable in height to those used in tree seedling nurseries. Tubes that are used in crops like grapes generally have unventilated walls. The tube material may be opaque or translucent. The base of the tube often is pushed into the soil to reduce the displacement of or damage to the tube from high wind, thereby minimizing maintenance costs.

A generalized energy balance equation for the interior air of a grow tube can be found in Bergez and Dupraz (2009). In the forestry literature, descriptions of tube microclimate largely have been limited to the aboveground environment (e.g., Bellot et al., 2002; Bergez and Dupraz, 1997, 2000, 2009), consistent with foresters' interest in tree diameter, tree height, and for some species, lower branch suppression. Above- and belowground biomass has been measured in some studies (Bellot et al., 2002; Bergez and Dupraz, 2000; Burger et al., 1997; Laliberté et al., 2008; Mayhead and Boothman, 1997; Oliet and Jacobs, 2007). Observations from forestry are readily transferable to crops like cultivated grapevines, where a minimum number of elongated trunks of adequate diameter are desired (Munnell, 2003). Unlike vines, the blueberry plant (Vaccinium corymbosum L.) grows as a bush; therefore, early in establishment, much shoot growth would occur inside the tube, where the effects of temperature and light on shoot growth might be quite different from what has been observed in either grapevines or trees.

In both forestry and grape production, the soil is minimally disturbed relative to production practices for a crop like blueberry where a tilled, mulch-incorporated and mulchcovered raised bed may be prepared. Thus, the blueberry plant's crown and root system is established in three strata: mulch, mulchincorporated soil, and tilled native soil. In the biennial production cycle of blueberry, growth of renewal fruit-producing wood and canes ("whips") originate from the plant crown. Thus, quantifying the tube microclimate requires monitoring the modified surface and soil as well as the aboveground environment. What is not known is the extent to which unventilated grow tubes with sealed bases (bottom pushed into the soil) influence temperatures that are relevant to crown growth and whip initiation. The objective of this study was to quantify the aboveground (temperature, humidity, solar radiation) and belowground (temperature) microclimate of two height-appropriate, unventilated, singlewall grow tubes (translucent, opaque) that were being used in commercial fields. We used blueberry grown on mulch-incorporated raised beds as a model crop. A forthcoming 
article will assess the integrated seasonal influence of grow tubes on blueberry plant growth during establishment.

\section{Materials and Methods}

The study was conducted in a commercial blueberry field near Salem, OR (lat. $45^{\circ} 00^{\prime} 59^{\prime \prime} \mathrm{N}$, long. $122^{\circ} 56^{\prime} 36^{\prime \prime} \mathrm{W}$ ) on a Woodburn silt loam (Fine-silty, mixed, superactive, mesic Aquultic Argixerolls). The soil was tilled and trapezoidal raised beds were mechanically formed with a base width of $\approx 120 \mathrm{~cm}$, a top width of $\approx 55 \mathrm{~cm}$, and total height of $\approx 25 \mathrm{~cm}$. A sawdust ( $91 \%$ of particles less than $4 \mathrm{~mm}$ ) amendment was incorporated into the top $15 \mathrm{~cm}$ of the bed before planting. Beds were $3.05 \mathrm{~m}$ apart on center. Standard commercial stock (18-month-old, 3.8-L container-grown) of northern highbush blueberry, cv. Liberty, with two to four whips each (1-year-old wood; whip diameter 4 to $7 \mathrm{~mm}$ ) were planted in the fall of 2005 in the center of the row at intervals of $0.75 \mathrm{~m}$. Surface drip tubes with $1.9-\mathrm{L} \cdot \mathrm{h}^{-1}$ emitters spaced $46 \mathrm{~cm}$ apart were laid at $\approx 15 \mathrm{~cm}$ to either side of the plant crown. Beds were irrigated daily in three 10-min sets. Sawdust mulch was drop-spread on top of the bed to a depth of $\approx 5 \mathrm{~cm}$. On day of year (DOY) 100 , one of two unventilated, single-wall grow tubes was installed over the plants: white translucent (Blehyl Farm Service, Grandview, WA) or beige opaque (Wilson Orchard and Vineyard Supply, Yakima, WA). Each tube type was $51 \mathrm{~cm}$ high and $20 \mathrm{~cm}$ in diameter. The bottom edge of the tube was pushed into the bed to form a lower boundary seal per standard commercial practice. Tubes were held in place by two vertical bamboo stakes. The planting otherwise was managed per standard commercial practices for blueberry production in Oregon (Strik et al., 1993).

The nominal transmissivity $(\tau)$ of each tube material was measured in triplicate from 200 to $800 \mathrm{~nm}$ by a spectrophotometer (DU 640; Beckman, Brea, CA). In its field installation, solar radiation also enters the tube through the top opening. Therefore, we computed an apparent transmissivity $\left(\tau^{\prime}\right)$ in the 400- to 700-nm waveband as the ratio between photosynthetic photon flux density (PPFD) inside the tube at $25 \mathrm{~cm}$ aboveground (midtube height) and incident $P P F D$ (Sharew and Hairston-Strang, 2005). The PPFD was measured by a silicon quantum sensor (LI-190; LI-COR, Lincoln, NE) in one empty tube per tube type. Sensor bases were supported by a vertical rod and were leveled. The tube diameter was too small to accommodate both a plant and the radiation sensor; we recognize this limitation and used the sensors to estimate $\tau$ ' for solar elevation angles across the season. The PPFD was measured as an indicator of heat transfer by solar radiation. Silicon PPFD sensors were used for their accurate spectral response in the visible waveband (400 to $700 \mathrm{~nm})$. By contrast, silicon pyranometers, which measure global irradiance, are calibrated for full sunlight and have a spectral error when used in a shaded environment (e.g., plant canopies, grow tubes; Klassen and Bugbee, 2005).

Nine plants were instrumented in a completely randomized design. There were three plants in each of the two tube types and three control plants with no tubes installed. Air temperature $\left(\mathrm{T}_{\mathrm{a}}\right)$ and relative humidity $(\mathrm{RH})$ at midtube height $(25 \mathrm{~cm}$ above the bed surface) were measured by custom-built T/RH sensors (Center for Precision Agricultural Systems, Washington State University, Prosser, WA) comprised of surface-mount thermistors (YSI 0603; YSI Temperature, Dayton, $\mathrm{OH}$ ) and integrated-circuit humidity sensors (HIH-3610; Honeywell, Freeport, IL). The T/RH sensors were shielded and aspirated. All sensors were calibrated against a reference (HMP-C; Vaisala, Helsinki, Finland). Saturation vapor pressure $\left(\mathrm{e}_{\mathrm{sat}}\right)$ was computed from $T_{a}$ using Murray's equation (Murray, 1967). Vapor pressure deficit (VPD) was computed from the difference between saturated and actual vapor pressure $\left(\mathrm{e}_{\mathrm{a}}\right)$ at $\mathrm{T}_{\mathrm{a}}$.

All temperatures other than $\mathrm{T}_{\mathrm{a}}$ were measured by Type $T$ thermocouples (copperconstantan) with three junctions wired in parallel for each measurement. Stem temperature $\left(\mathrm{T}_{\text {stem }}\right)$ was measured by fine-wire [0.127 mm diam (36 gauge)] thermocouples at midtube height on three whips per plant on the north aspect of the whips to minimize radiation error. Junctions were inserted just beneath the bark surface in a small slit and
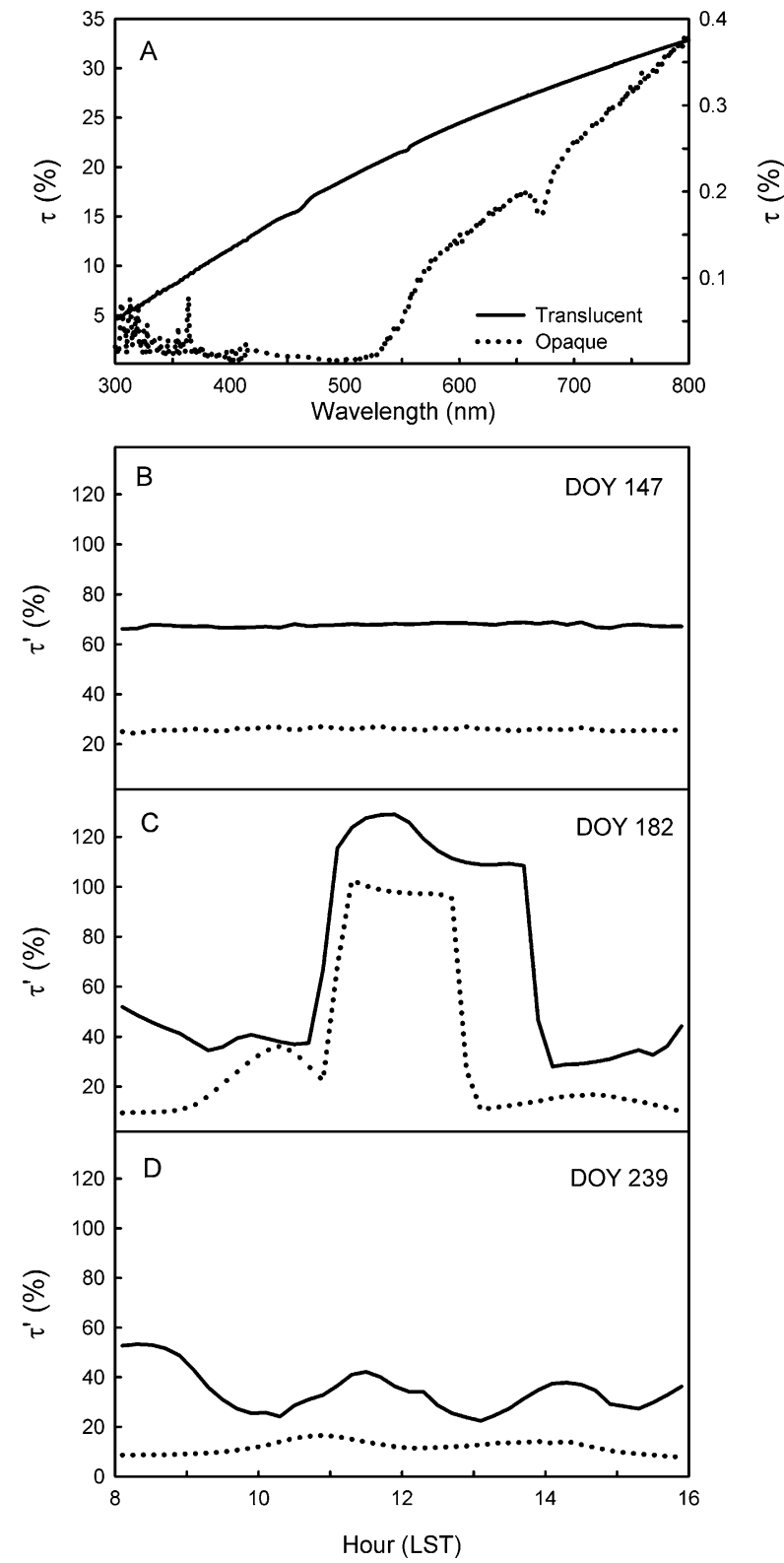

Fig. 1. Nominal transmissivity $(\tau)$ of translucent and opaque grow tube materials as measured by a spectrophotometer $(\mathbf{A})$. Note vertical axis scale for each material. Apparent transmissivity $\left(\tau^{\prime}\right)$ of the tube assembly in situ in the 400 to $700 \mathrm{~nm}$ waveband for (B) $1 \mathrm{~d}$ with overcast skies; (C) $1 \mathrm{~d}$ with clear skies in midsummer; and (D) $1 \mathrm{~d}$ with clear skies at lower maximum solar elevation angle. The $\tau$ ' was computed as the ratio between photosynthetic photon flux density (PPFD) inside the tube at $25 \mathrm{~cm}$ aboveground (midtube height) and incident $P P F D$. 
then were secured with grafting tape. Despite 1-year-old canes being non-transpiring organs, we measured $\mathrm{T}_{\text {stem }}$ rather than leaf temperature for more robust sampling, standard sampling height, and to ensure continuous thermocouple contact for the 6-month measurement period, thus eliminating any need for tube removal. Mulch surface temperature $\left(\mathrm{T}_{\text {mulch }}\right)$ was measured by sawdust-encapsulated fine-wire thermocouples. Temperature at the mulch-bed interface $\left(\mathrm{T}_{\mathrm{sm}}\right)$ was measured by $0.5-\mathrm{mm}$ diam (24-gauge) thermocouples that had been inserted into the center of $2.5-\mathrm{cm}$ long steel tubing (3-mm inner diam) and sealed with epoxy. Thermocouples were inserted into the soil immediately below the mulch. Soil temperature at $15 \mathrm{~cm}$ below the soil-mulch interface $\left(\mathrm{T}_{\text {soil }}\right)$ was measured using an identical method. For $\mathrm{T}_{\text {sm }}$ and $\mathrm{T}_{\text {soil }}$, a face was excavated $\approx 6 \mathrm{~cm}$ to the side of the plant crown and the thermocouples were inserted into undisturbed soil to ensure soil-sensor contact.

Meteorological variables were measured at a reference height of $2 \mathrm{~m}$ aboveground. Global irradiance was measured by pyranometer (Model 8-48; Eppley Laboratories, Newport, RI). Incident PPFD was measured like in the grow tubes. Wind speed and direction were measured by a three-cup anemometer and wind vane (Wind Sentinel; MetOne, Grants Pass, OR). The $\mathrm{T}_{\mathrm{a}}$ and $\mathrm{RH}$ were measured by the same sensor as noted previously. Signals from all sensors were scanned every $5 \mathrm{~s}$ and averaged every $12 \mathrm{~min}$ by a multiplexed data logger system (AM-416 and CR-10X; Campbell Scientific, Logan, UT). The duration of the measurements was from DOY 110 to 293, 2006. Data were postprocessed using SAS (Version 9.3; SAS Institute, Cary, NC) and mean values of the three replications are presented.

\section{Results}

The average $\tau$ in the visible waveband was $21.2 \%$ for the translucent material and $0.1 \%$ for the opaque material (Fig. 1A). Considered between 0600 and 1800 HR local standard time (LST), $\tau$ ' (tube assembly in situ) was consistent across the day under overcast skies (DOY 147), where solar radiation was diffuse (Fig. 1B). Under clear skies, $\tau$ ' varied with solar elevation angle (SEL). In midsummer (DOY 182, SEL 68 ${ }^{\circ}$; Fig. 1C), there was a midday peak where $P P F D$ inside the tube exceeded incident $P P F D$, indicating multiple reflections from the inner tube walls. Later in the season (DOY 239; Fig. 1D) at lower maximum SEL $\left(55^{\circ}\right)$, we did not observe this phenomenon. Although the upper plant canopy in the tubes may have been subjected to more extreme diurnal fluctuation in PPFD than ambient, integrated over the day, available radiation was substantially lower in the tubes. Over $3 \mathrm{~d}$ with clear skies in midsummer (DOY 182 to 184 ), mean $\tau^{\prime}$ were $65 \%$ and $35 \%$ for the translucent and opaque tubes, respectively. Later in the season (DOY 238 to 240) under clear skies,
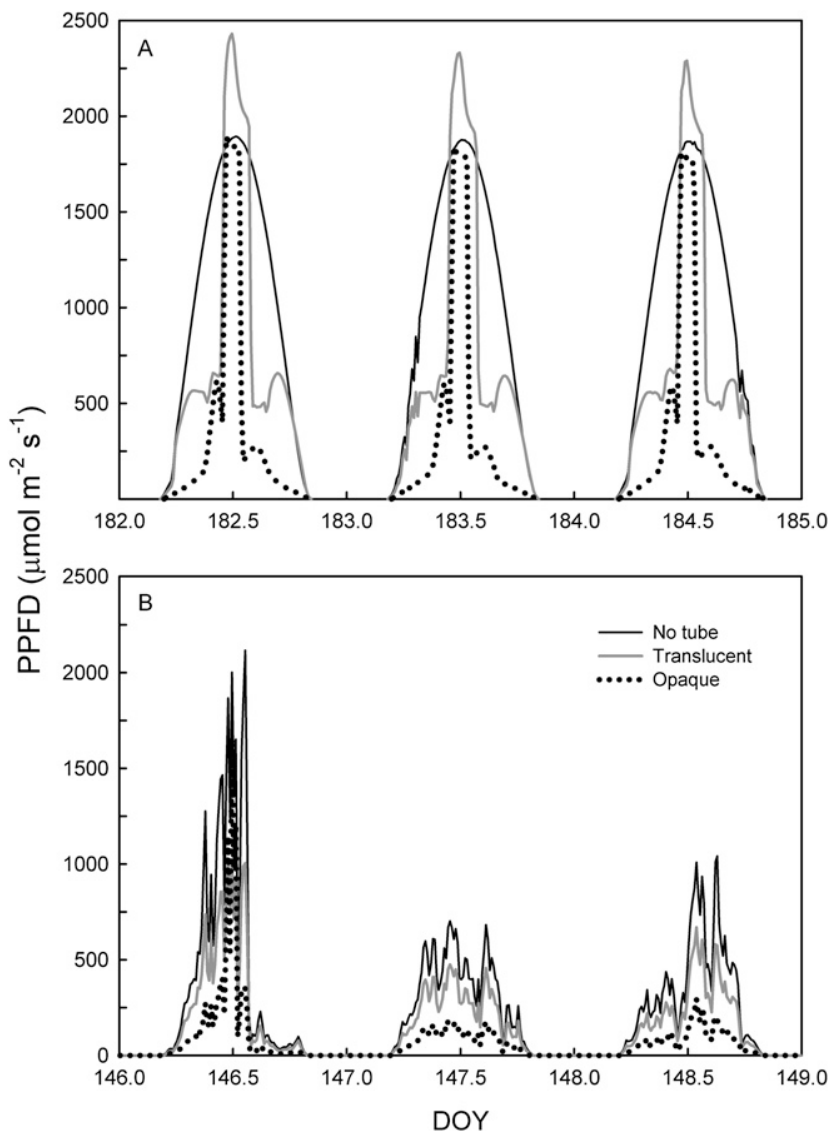

Fig. 2. Diurnal patterns of incident photon flux density $(P P F D)$ and $P P F D$ inside a translucent and an opaque grow tube (A) under clear skies and (B) under partly cloudy to overcast skies. DOY = day of year.

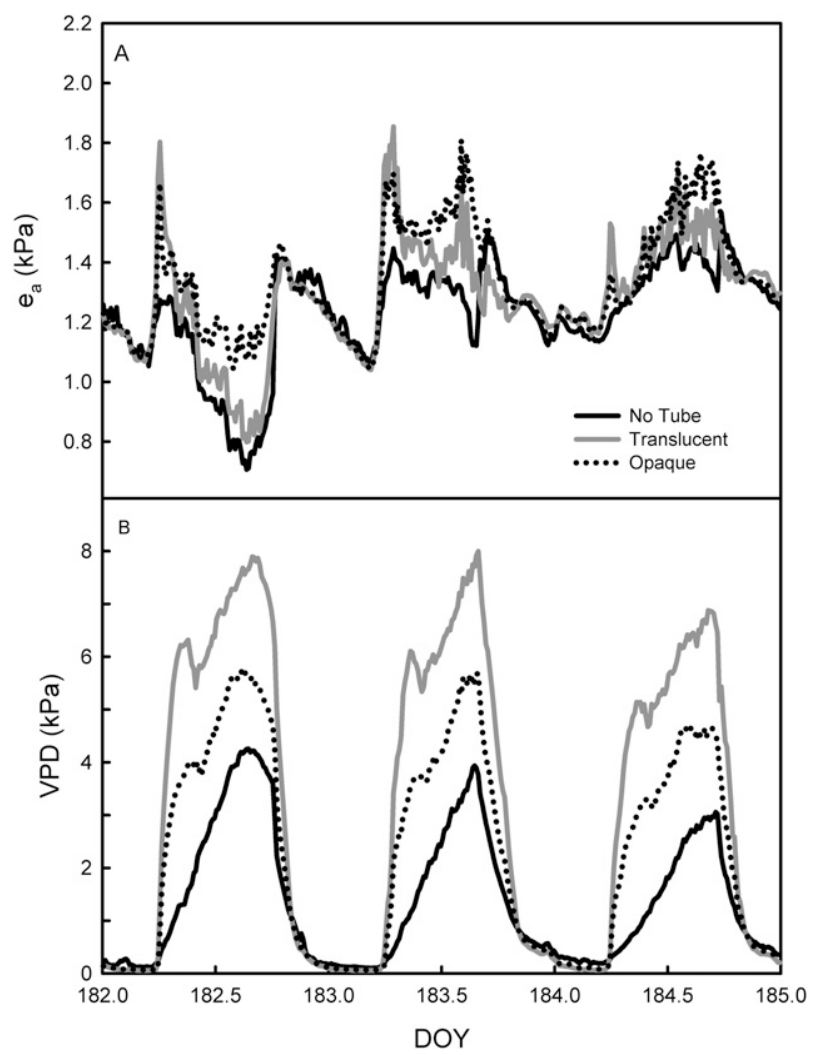

Fig. 3. Diurnal patterns of $(\mathbf{A})$ actual vapor pressure $\left(e_{a}\right)$ and $(\mathbf{B})$ vapor pressure deficit (VPD) outside a grow tube and inside a translucent and an opaque grow tube under clear skies. DOY $=$ day of year. 
mean $\tau$ ' was $35 \%$ for the translucent tube and $12 \%$ for the opaque tube. The diurnal pattern of $P P F D$ in our tubes reflected that of $\tau$ ' (Fig. 2).

Under clear skies in midsummer, $\mathrm{e}_{\mathrm{a}}$ in the grow tubes was only slightly higher than ambient (Fig. 3A). However, because $T_{a}$ in the tubes was as much as $20^{\circ} \mathrm{C}$ higher than ambient, VPD values were much higher in the tubes (Fig. 3B). Under cloudy or overcast skies, we measured little difference in $e_{a}$ or VPD between tubes and ambient (data not shown).

Above- and belowground temperatures were tightly coupled with incident radiation (Figs. 4 to 8). Consistent with other studies using unventilated tubes (e.g., Bergez and Dupraz, 2000; Kjelgren, 1994; Munnell, 2003), during the day, we found $T_{a}$ to be above ambient in both tubes whether under clear or overcast skies (Fig. 4). The $\mathrm{T}_{\mathrm{a}}$ in the opaque tube was intermediate between ambient and that in the translucent tube. Under clear skies, the maximum difference in air temperature $\left(\Delta \mathrm{T}_{\mathrm{a}}\right)$ between the translucent tube and ambient was $19.7^{\circ} \mathrm{C}$. The maximum $\Delta \mathrm{T}_{\mathrm{a}}$ between the translucent and opaque tubes was $7.6^{\circ} \mathrm{C}$. We observed average daily temperature maxima for translucent and opaque tubes of 44.4 and $39.8{ }^{\circ} \mathrm{C}$, respectively, whereas that of ambient $\mathrm{T}_{\mathrm{a}}$ was $33.6{ }^{\circ} \mathrm{C}$. The $\mathrm{T}_{\mathrm{a}}$ peaked at similar times of the day inside and outside the tubes. Under overcast skies (DOY 147; Fig. 4B) the maximum $\Delta \mathrm{T}_{\mathrm{a}}$ between the translucent tube and ambient was $\approx 6{ }^{\circ} \mathrm{C}$, whereas that between the opaque tube and ambient was $2.0^{\circ} \mathrm{C}$. At night, $\Delta \mathrm{T}_{\mathrm{a}}$ between inside and outside the tubes was less than $2{ }^{\circ} \mathrm{C}$ (Fig. 4), similar to that reported elsewhere (Bergez and Dupraz, 2000, 2009; Kjelgren, 1994), although less than that observed by Swistock et al. (1999). At night $\mathrm{T}_{\mathrm{a}}$ in the translucent tube approximated that in the opaque tube.

The maximum differences in $\mathrm{T}_{\text {stem }}$ between tubes and ambient (Fig. 5A) were much lower $\left(+8.7{ }^{\circ} \mathrm{C}\right.$, translucent; $+6.6{ }^{\circ} \mathrm{C}$, opaque) than those of $\mathrm{T}_{\mathrm{a}}$. Under clear skies, ambient $\mathrm{T}_{\text {stem }}$ during the day exceeded $\mathrm{T}_{\mathrm{a}}$ by up to $4{ }^{\circ} \mathrm{C}$ (Fig. 5B), indicating that the radiation load on the dark surface of the thin cane was not balanced by convective heat transfer. Mean daytime wind speed during the same period was 2.0 to $2.2 \mathrm{~m} \cdot \mathrm{s}^{-1}$ with maxima on the order of $4.5 \mathrm{~m} \cdot \mathrm{s}^{-1}$ (data not shown). By contrast, $\mathrm{T}_{\mathrm{a}}$ exceeded $\mathrm{T}_{\text {stem }}$ inside the tubes. The magnitude of differences between $\mathrm{T}_{\mathrm{a}}$ and $\mathrm{T}_{\text {stem }}$ inside the tubes (translucent $>$ opaque) reflected PPFD (Fig. 2) with $\mathrm{T}_{\mathrm{a}}-\mathrm{T}_{\text {stem }}$ in the translucent tube $2.1^{\circ} \mathrm{C}$ higher on average than in the opaque tube during days with clear skies (mean maximum difference $3.6{ }^{\circ} \mathrm{C}$ ). Under overcast skies, $\mathrm{T}_{\text {stem }}$ in the translucent tube exceeded that in the opaque tube by $1.1{ }^{\circ} \mathrm{C}$ on average during the day $\left(2.3{ }^{\circ} \mathrm{C}\right.$ maximum; data not shown). At night, $\mathrm{T}_{\mathrm{a}}$ and $\mathrm{T}_{\text {stem }}$ differed by less than $1{ }^{\circ} \mathrm{C}$ whether inside or outside of a tube.

Reduced radiation incident on the mulch surface inside the grow tubes was reflected in

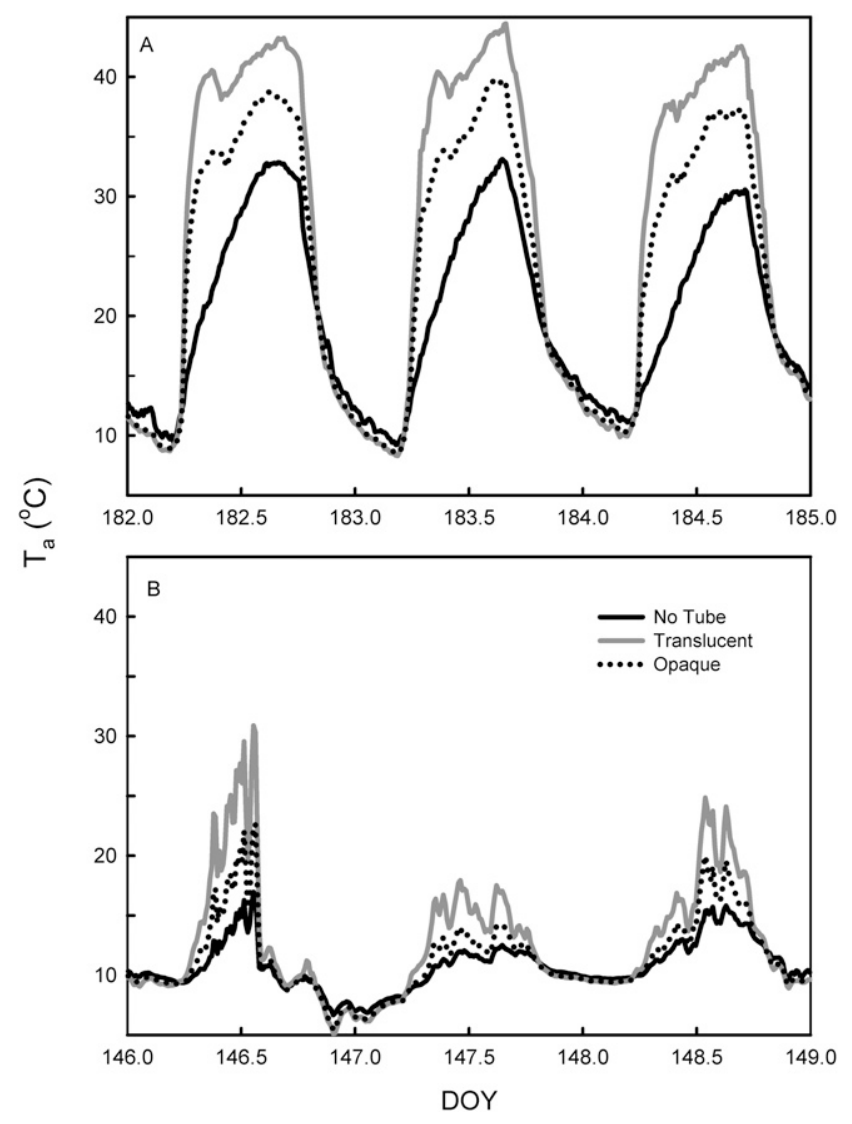

Fig. 4. Diurnal patterns of aboveground $(25 \mathrm{~cm})$ air temperature $\left(\mathrm{T}_{\mathrm{a}}\right)$ outside a grow tube and inside a translucent and an opaque tube (A) under clear skies and (B) under overcast or cloudy skies. DOY = day of year.

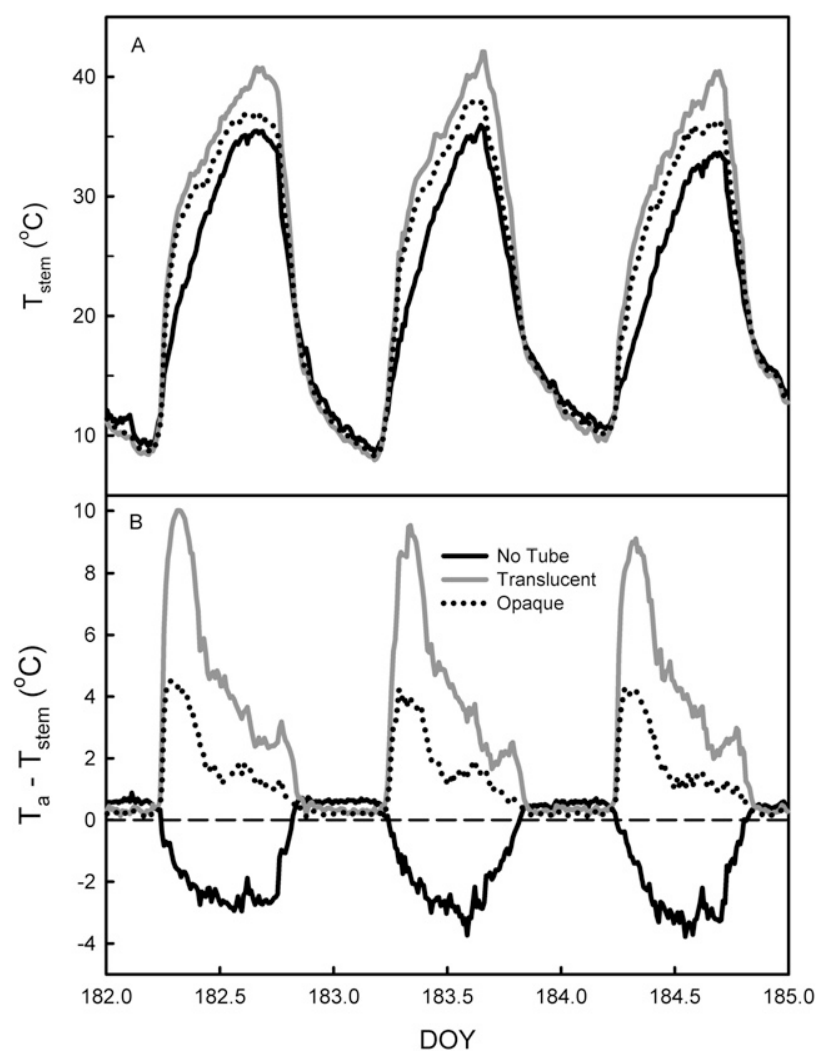

Fig. 5. (A) Diurnal patterns of stem temperature $\left(\mathrm{T}_{\text {stem }}\right)$ at $25 \mathrm{~cm}$ aboveground outside a grow tube and inside a translucent and an opaque tube under clear skies, and $(\mathbf{B})$ differences between air $\left(\mathrm{T}_{\mathrm{a}}\right)$ and stem temperatures $\left(\mathrm{T}_{\text {stem }}\right)$ in the absence of a grow tube and inside a translucent and an opaque grow tube. $\mathrm{DOY}=$ day of year. 
lower than ambient daytime $\mathrm{T}_{\text {mulch }}$ (Fig. 6A) by as much as $14.6^{\circ} \mathrm{C}$ for the translucent tube and $20.5^{\circ} \mathrm{C}$ for the opaque tube. The $\mathrm{T}_{\text {mulch }}$ in the translucent tube was up to $11{ }^{\circ} \mathrm{C}$ higher than that in the opaque tube. At the low ventilation rates characteristic of these grow tubes, the daytime average difference between $\mathrm{T}_{\mathrm{a}}$ and $\mathrm{T}_{\text {mulch }}\left(\mathrm{T}_{\mathrm{a}}>\mathrm{T}_{\text {mulch }}\right)$ of $1.5{ }^{\circ} \mathrm{C}$ (translucent) and $3.6^{\circ} \mathrm{C}$ (opaque) indicates a much lower heat flux between the mulch surface and the air in the tube than under ambient conditions. Maximum ambient $\mathrm{T}_{\text {mulch }}$ was $53{ }^{\circ} \mathrm{C}$, indicating a high radiation load on a dry surface with low thermal conductivity. Daily maximum $\mathrm{T}_{\text {mulch }}$ did not occur simultaneously inside and outside the tubes; $\mathrm{T}_{\text {mulch }}$ peaked later in the day inside both tubes. Neither daytime nor nighttime ambient $T_{\text {mulch }}$ was correlated with bulk wind speed. We did not measure wind speed at the mulch surface nor estimate the thickness of the boundary layer. The maximum diurnal amplitude of $\mathrm{T}_{\text {mulch }}$ was $44^{\circ} \mathrm{C}$ outside of a tube, $37{ }^{\circ} \mathrm{C}$ in the translucent tube, and $26^{\circ} \mathrm{C}$ in the opaque tube. Under overcast skies (Fig. 6B), ambient $\mathrm{T}_{\text {mulch }}$ averaged $0.6{ }^{\circ} \mathrm{C}$ below that in the translucent tube and $1.3{ }^{\circ} \mathrm{C}$ above that in the opaque tube. At night, ambient $\mathrm{T}_{\text {mulch }}$ was less than $1.5^{\circ} \mathrm{C}$ lower than that in either tube, indicating small but negative net radiation from the mulch outside of a tube.

Maximum daily $\mathrm{T}_{\mathrm{sm}}$ were $29.3^{\circ} \mathrm{C}$ (ambient), $27.7^{\circ} \mathrm{C}$ (translucent tube), and $26.6^{\circ} \mathrm{C}$ (opaque tube; Fig. 7A). Under clear skies, there was a much lower daily amplitude in $\mathrm{T}_{\mathrm{sm}}$ than in $\mathrm{T}_{\text {mulch }}$ in all cases, varying between a maximum of $11.5^{\circ} \mathrm{C}$ without a tube to $9{ }^{\circ} \mathrm{C}$ in the opaque tube. Under overcast skies, daily amplitude did not exceed 3.3 to $3.5{ }^{\circ} \mathrm{C}$ in either tube and $6{ }^{\circ} \mathrm{C}$ under ambient conditions (data not shown). There was a large gradient between $\mathrm{T}_{\text {mulch }}$ and $\mathrm{T}_{\mathrm{sm}}$ (Fig. 7B).

The mean daytime difference in $T_{\text {soil }}$ between tubes and ambient was less than $0.6^{\circ} \mathrm{C}$ (Fig. 8A). Under clear skies, the daily amplitude in $\mathrm{T}_{\text {soil }}$ did not exceed $2.3{ }^{\circ} \mathrm{C}$ without a tube and $\approx 1.8^{\circ} \mathrm{C}$ under either tube. The gradient between $\mathrm{T}_{\mathrm{sm}}$ and $\mathrm{T}_{\text {soil }}$ was much lower than that of $\mathrm{T}_{\text {mulch }}$ and $\mathrm{T}_{\mathrm{sm}}$, whether inside or outside of a tube (Figs. 7B and 8B). The $\mathrm{T}_{\mathrm{sm}}-\mathrm{T}_{\text {soil }}$ was highest without a grow tube $\left(11.4{ }^{\circ} \mathrm{C}\right)$, indicative of a higher driving force for heat flux from the top to the base of the mulch-incorporated soil than existed inside the tubes. Both tubes had similar maximum $\mathrm{T}_{\mathrm{sm}}-\mathrm{T}_{\text {soil }}\left[4.4{ }^{\circ} \mathrm{C}\right.$ (translucent); $3.8^{\circ} \mathrm{C}$ (opaque)]. The average $\mathrm{T}_{\mathrm{sm}}-\mathrm{T}_{\text {soil }}$ was negative at night, ranging from $-4.8^{\circ} \mathrm{C}$ (opaque) to $-3.9^{\circ} \mathrm{C}$ (translucent). Ambient conditions were intermediate $\left(-4.2^{\circ} \mathrm{C}\right)$.

Given the bed length of the study area $(\approx 8 \mathrm{~m})$, we assume uniform application of drip irrigation and uniformity in the composition of the sawdust-incorporated soil and the native tilled soil of the raised bed. At a given soil water content, soil thermal conductivity is inversely related to aggregate size (Usowicz et al., 2013). There were large differences in bulk density and organic matter content in this

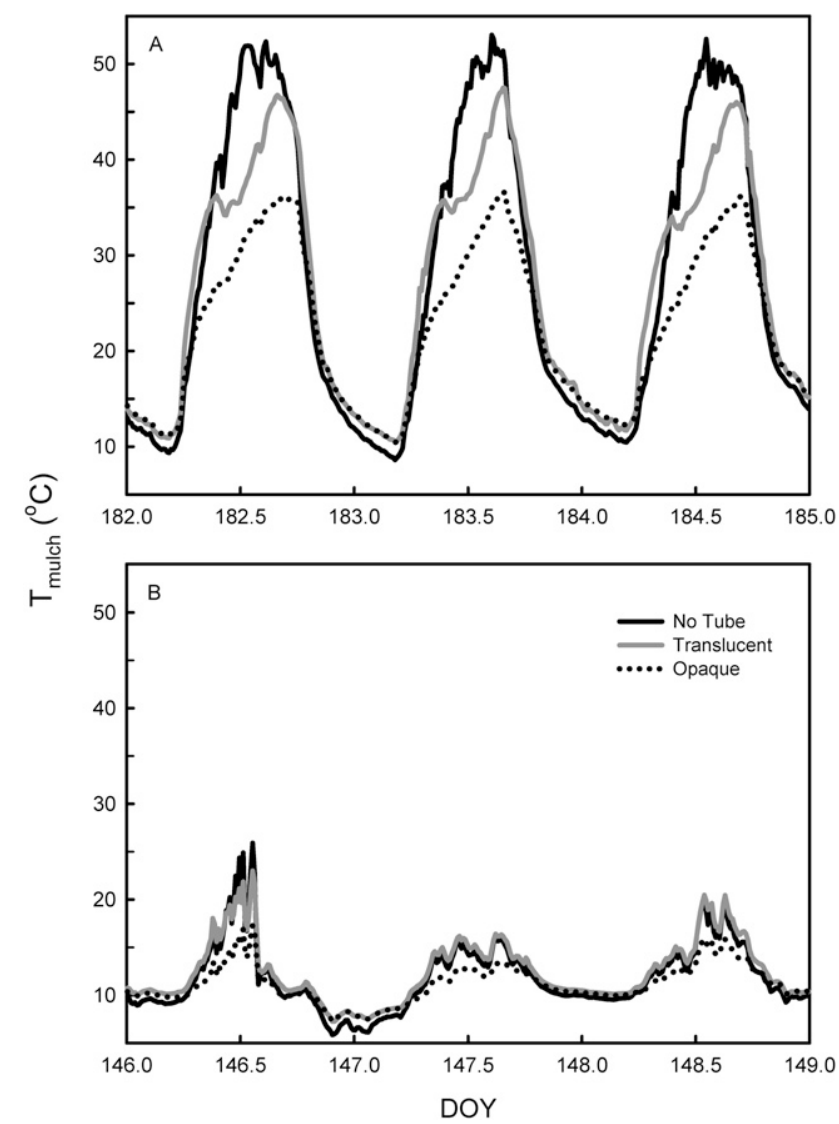

Fig. 6. Diurnal patterns of the surface temperature of dry sawdust mulch $\left(\mathrm{T}_{\text {mulch }}\right)$ outside a grow tube and inside a translucent and an opaque tube $(\mathbf{A})$ under clear skies and (B) under overcast or cloudy skies. DOY $=$ day of year.

bed system, where the sawdust had a bulk density of $0.16 \mathrm{~g} \cdot \mathrm{cm}^{-3}$, the mulch-incorporated soil $0.57 \mathrm{~g} \cdot \mathrm{cm}^{-3}$, and the tilled soil forming the lower boundary of the bed $1.13 \mathrm{~g} \cdot \mathrm{cm}^{-3}$ ( 15 to $25 \mathrm{~cm}$ below the surface).

\section{Discussion}

The observed phenomenon of midday $P P F D$ in the tubes exceeding incident was the result of the combination of radiation impinging on the sensor at maximum SEL and internal reflections from the tube wall. The degree to which a plant canopy fills the area of the tube would determine the degree to which this effect would be damped. In another context, a surface energy balance of a sparse crop, irradiance at the soil surface sometimes exceeded incident irradiance because of that reflected from the plant canopy (Ham and Kluitenberg, 1993). In terms of $\tau$ ' integrated over the day, our later-season findings were quite similar to those of a forest understory study, where transmitted PPFD $(\tau$ ') between 1200 and 1500 HR LST measured on $1 \mathrm{~d}$ averaged $34 \%$ for a translucent tube and $12 \%$ for an opaque tube (Sharew and Hairston-Strang, 2005). In the present study, for substantial portions of the day, PPFD in both tubes, but particularly in the opaque tube, was well below an approximate light saturation level for photosynthesis in blueberry that has been reported for two commercial cultivars: Bluecrop [600 to $700 \mu \mathrm{mol} \cdot \mathrm{m}^{-2} \cdot \mathrm{s}^{-1}$ (Rho et al., 2012); and 700 to $900 \mu \mathrm{mol} \cdot \mathrm{m}^{-2} \cdot \mathrm{s}^{-1}$ (Moon et al., 1987)] and Jersey (600 to $800 \mu \mathrm{mol} \cdot \mathrm{m}^{-2} \cdot \mathrm{s}^{-1}$; Moon et al., 1987). In addition, shading appears to reduce the number of whips per bush (Kim et al., 2011).

Our observations of VPD are consistent with those for Quercus ilex seedlings in unventilated translucent tubes, where VPD in the tubes was significantly higher than ambient (Oliet and Jacobs, 2007). However, their absolute values were lower than ours, which can be attributed to their lower $\mathrm{T}_{\mathrm{a}}$ and reported high rates of transpiration by the trees. In Prunus avium seedlings, daily total transpiration inside an unventilated translucent grow tube was $8 \%$ of that measured on an unsheltered tree (Bergez and Dupraz, 1997). In blueberry, Moon et al. (1987) found a $67 \%$ to $80 \%$ reduction in transpiration in response to a small change in VPD: from 1 to $3 \mathrm{kPa}$. They also noted an associated decrease in stomatal conductance $(56 \%$ to $60 \%)$ that influenced transpiration more than it did net photosynthesis. Given their evidence, it is reasonable to suspect low transpiration by the plants in our tubes.

The maximum $\Delta \mathrm{T}_{\mathrm{a}}$ that we observed was similar to maximum differences found by Hall and Mahaffee (2001; up to $19.7^{\circ} \mathrm{C}$ ) and by Kjelgren et al. (1997; up to $18^{\circ} \mathrm{C}$ ). However, our maximum $\Delta \mathrm{T}_{\mathrm{a}}$ exceeded those found in most other reports (e.g., Bellot 


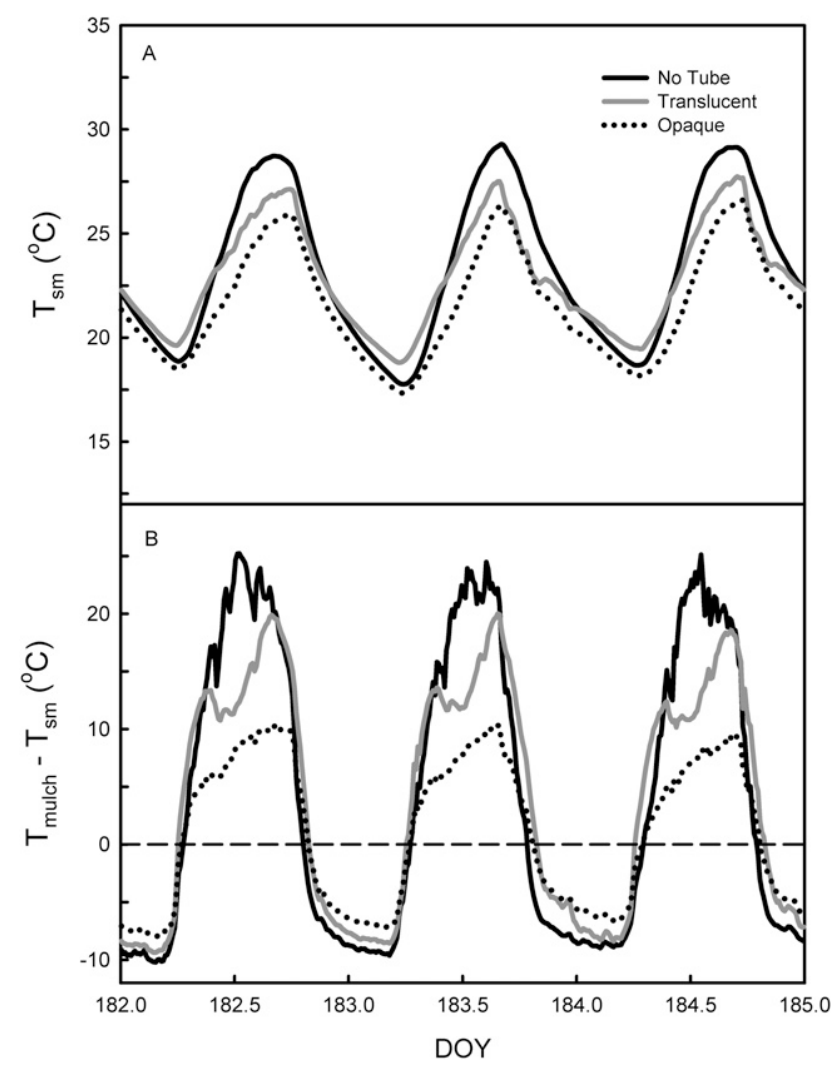

Fig. 7. (A) Diurnal patterns of soil temperature at the interface between the sawdust mulch and the mulchincorporated soil $\left(\mathrm{T}_{\mathrm{sm}}\right)$ outside a grow tube and inside a translucent and an opaque tube under clear skies and (B) differences in temperature between the sawdust mulch surface $\left(T_{\text {mulch }}\right)$ and $T_{\text {sm }}$ in the absence of a grow tube and inside a translucent and an opaque grow tube. DOY = day of year.

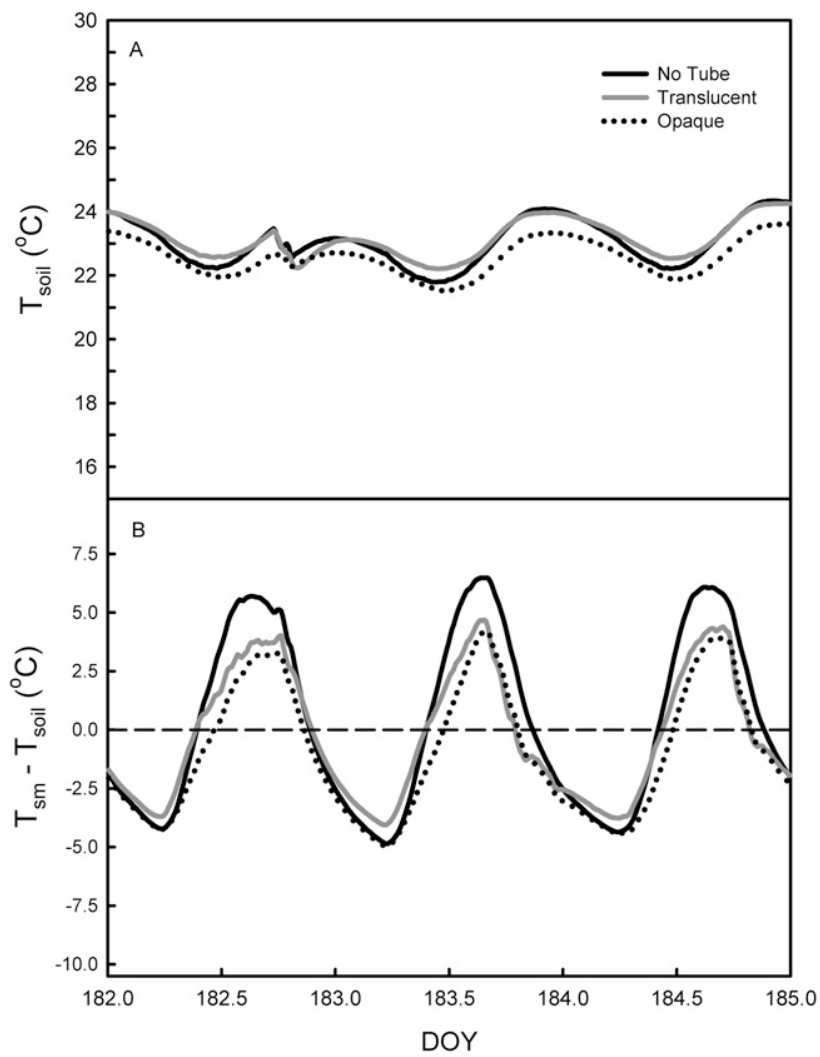

Fig. 8. (A) Diurnal patterns of temperature in the native tilled soil $\left(\mathrm{T}_{\text {soil }}\right)$ at $15 \mathrm{~cm}$ below the mulch-soil interface outside of a grow tube and inside a translucent and an opaque tube under clear skies and (B) differences in temperature between the mulch-soil interface $\left(\mathrm{T}_{\mathrm{sm}}\right)$ and $\mathrm{T}_{\text {soil }}$ in the absence of a grow tube and inside a translucent and an opaque grow tube. DOY = day of year. et al., 2002; Bergez and Dupraz, 2000, 2009; Kjelgren, 1994; Munnell, 2003). Among studies that used unventilated translucent tubes, direct comparisons of $\Delta \mathrm{T}_{\mathrm{a}}$ under similar incident PPFD are difficult because of unknown differences in $\tau$ ', which was reported in only a few instances (Bellot et al., 2002; Munnell, 2003). Few studies have included temperature measurements in opaque tubes but in one case, contrary to our findings, daytime $\mathrm{T}_{\mathrm{a}}(1 \mathrm{~d})$ was below ambient (cardboard milk carton; Munnell, 2003). In the same work, $\tau$ ' varied between $0 \%$ at $400 \mathrm{~nm}$ and $20 \%$ at $700 \mathrm{~nm}$.

The treatments we studied affected temperature and PPFD and thus may have affected photosynthesis, which we did not measure. In other studies, a temperatureresponse curve for net photosynthesis in two commercial highbush blueberry cultivars was curvilinear with an optimum of 14 to $22{ }^{\circ} \mathrm{C}$ for 'Bluecrop' and 18 to $26{ }^{\circ} \mathrm{C}$ for 'Jersey' (Moon et al., 1987). At $35^{\circ} \mathrm{C}$, net photosynthesis in both cultivars decreased to $\approx 4 \mu \mathrm{mol} \cdot \mathrm{m}^{-2} \cdot \mathrm{s}^{-1}$ from a high of 9 to $10 \mu \mathrm{mol} \cdot \mathrm{m}^{-2} \cdot \mathrm{s}^{-1}$ in the optimum temperature range. In 'Bluecrop' and 'Elliott', a parent of 'Liberty', photosynthesis decreased by $24 \%$ to $27 \%$ when $\mathrm{T}_{\mathrm{a}}$ increased from 20 to $30{ }^{\circ} \mathrm{C}$ (Hancock et al., 1992). The temperature and light regimes in our two grow tubes indicate that the rate of photosynthesis would have been reduced for shoots inside the tubes.

By definition, both plastic tubes are characterized by low ventilation rates. Air exchange in the tubes primarily is by free convection with some forced convection only during wind-induced incursion of air through the tube opening $\left(314 \mathrm{~cm}^{2}\right)$. Baird and Legree (1994) used a one-dimensional model to describe free convection in a heated, unventilated cardboard tube ( $2 \mathrm{~m}$ tall; 21 to $28 \mathrm{~cm}$ diam) and found that effective mixing lengths were on the order of the tube diameter. The average wind speed in an unventilated translucent grow tube with a sealed base ( $1.22 \mathrm{~m}$ tall, 7 to $10 \mathrm{~cm}$ diam) was reported as less than $0.1 \mathrm{~m} \cdot \mathrm{s}^{-1}$ (Kjelgren, 1994). Estimated from air exchange rates, wind speeds in other unventilated tubes with sealed bases ( $2.1 \mathrm{~m}$ tall, $10 \mathrm{~cm}$ diam) were 0.003 to $0.02 \mathrm{~m} \cdot \mathrm{s}^{-1}$ (Bergez and Dupraz, 1997, 2000). Dupraz and Bergez (1999) found no significant correlation between ventilation rates in an unventilated tube and mean bulk wind speed; likewise, no significant correlation was found between bulk wind speed and $\Delta \mathrm{T}_{\mathrm{a}}$ between ambient and the unventilated tube. We also found no significant correlation between bulk wind speed and $\Delta \mathrm{T}_{\mathrm{a}}$ between ambient and either tube.

Our study site was in a maritime climate with dry summers; between DOY 152 (1 June) and DOY 273 (30 Sept.), $50 \mathrm{~mm}$ of rain fell (Aurora, OR, U.S. Bureau of Reclamation, AgriMet station; <http:/www.usbr.gov/pn/ agrimet/webarcread.html $>$ ). In the absence of rain, the sawdust remained dry because drip irrigation was applied below the surface. Outside a grow tube, the mulch was a consistent source of sensible heat flux away 
from the surface during the day $\left(\mathrm{T}_{\text {mulch }}>\mathrm{T}_{\text {air }}\right)$. Despite the high temperature gradient between $\mathrm{T}_{\text {mulch }}$ and $\mathrm{T}_{\text {sm }}$, one would not anticipate large conductive fluxes as can occur in bed systems with high mulch-to-surface contact (Tarara and Ham, 1999). The sawdust mulch was applied uniformly using a mechanical spreader but was in loose contact with the mulch-incorporated soil, making it an effective insulator. In an oven-dry sawdust (particle size less than $6 \mathrm{~mm}$ ), thermal conductivity was $0.095 \mathrm{~W} \cdot \mathrm{m}^{-1} \cdot \mathrm{K}^{-1}, \approx 25 \%$ of that for a dry fine sand (Deng et al., 1992) and approximately half that of a generalized loam soil at $0 \%$ volume fraction of water (Campbell and Norman, 1998).

The response to temperature of crown growth in highbush blueberry has not been established. With respect to roots, in a $15-\mathrm{cm}$ deep sawdust mulch without a raised bed, optimum temperature for the growth of new unsuberized roots was estimated at 14 to $18^{\circ} \mathrm{C}$ (Abbott and Gough, 1987). Given their reported daily average temperature $\left(22{ }^{\circ} \mathrm{C}\right.$; DOY 186) at $15 \mathrm{~cm}$ below the surface (comparable to our $\mathrm{T}_{\mathrm{sm}}$ ), it would not be unreasonable to assume that their $\mathrm{T}_{\text {mulch }}$ and $\mathrm{T}_{\mathrm{sm}}$ often would have exceeded high temperature thresholds for root growth. In 5-year-old highbush blueberry in a bed system identical to ours, the bulk of the root system was between the surface and $25 \mathrm{~cm}$ with the highest root length density at $15 \mathrm{~cm}$ below the surface (Bryla and Strik, 2007). A few roots were found as deep as $40 \mathrm{~cm}$. Based on our values of $\mathrm{T}_{\text {soil }}$, the presence of a grow tube was essentially inconsequential at the depth of the anticipated highest root length density. In young blueberry plants, root distribution by depth is not known.

In a sawdust mulch-incorporated, raised bed system, grow tubes impart a larger change in the aerial environment and at the surface than they do in the near-surface mulch-incorporated soil and the tilled native soil. Our aboveground findings substantiated those in the forestry literature albeit $\Delta \mathrm{T}_{\mathrm{a}}$ were among the highest reported. Temperatures of the sawdust mulch would likely influence blueberry crown growth and the emergence of renewal wood or whips from the crown. Outside of a tube, high daytime $\mathrm{T}_{\text {mulch }}$ could excessively raise crown temperatures. Because of lower than incident $P P F D$, the sawdust mulch inside both tubes was subject to fewer extreme temperatures; thus, there may not be a strong influence of $\mathrm{T}_{\text {mulch }}$ per se. Nonetheless, in midsummer, $\mathrm{T}_{\text {mulch }}$ in the translucent tubes periodically briefly exceeded $45^{\circ} \mathrm{C}$. Contrary to ambient conditions, any whips emerging from the crown inside the grow tubes could be influenced as much by near-surface air temperature as by surface temperature. We did not observe extreme temperatures in the soil-mulch interface, but under clear skies, temperature maxima often exceeded those that have been identified as optimal for new root growth. The presence of a grow tube appeared to have no effect on the temperature of the native tilled soil ( $15 \mathrm{~cm}$ below the soil surface), where the highest density of roots may be expected.

\section{Literature Cited}

Abbott, J.D. and R.E. Gough. 1987. Seasonal development of highbush blueberry roots under sawdust mulch. J. Amer. Soc. Hort. Sci. 112:60-62.

Baird, M.H.I. and B.A. Legree. 1994. Natural convective heat transfer from open vertical tubes. Can. J. Chem. Eng. 72:755-758.

Bellot, J., J.M. Ortiz de Urbina, A. Bonet, and J.R. Sánchez. 2002. The effects of treeshelters on the growth of Quercus coccifera L. seedlings in a semiarid environment. Forestry 75:89-106

Bergez, J.-E. and C. Dupraz. 1997. Transpiration rate of Prunus avium L. seedlings inside an unventilated shelter. For. Ecol. Mgt. 97:255264.

Bergez, J.-E. and C. Dupraz. 2000. Effect of ventilation on growth of Prunus avium seedlings grown in treeshelters. Agr. For. Meteorol. 104:199-204.

Bergez, J.-E. and C. Dupraz. 2009. Radiation and thermal microclimate in tree shelter. Agr. For. Meteorol. 149:179-186.

Bryla, D.R. and B.C. Strik. 2007. Effects of cultivar and plant spacing on the seasonal water requirements of highbush blueberry. J. Amer. Soc. Hort. Sci. 132:270-277.

Burger, D.W., G.W. Forister, and R. Gross. 1997. Short and long-term effects of treeshelters on the root and stem growth of ornamental trees. J. Aboric. 23:49-56.

Campbell, G.S. and J.M. Norman. 1998. Environmental biophysics. 2nd Ed. Springer, New York, NY.

Deng, Y., C.B. Fedler, and J.M. Gregory. 1992. Predictions of thermal characteristics for mixed porous media. J. Mater. Civ. Eng. 4:185-195.

Due, G. 1990. The use of polypropylene shelters in grapevine establishment-A preliminary trial. Aust. Grapegrower Winemaker June: 29-33.

Dupraz, C. and J.-E. Bergez. 1999. Carbon dioxide limitation of the photosynthesis of Prunus avium $\mathrm{L}$. seedlings inside an unventilated treeshelter. For. Ecol. Mgt. 119:89-97.

Gerhold, H.D. 1999. Species differ in response to tree shelters. J. Aboric. 25:76-80.

Hall, T.W. and W.F. Mahaffee. 2001. Impact of vine shelter use on development of grape powdery mildew. Amer. J. Enol. Viticult. 52:204 209.

Ham, J.M. and G.J. Kluitenberg. 1993. Positional variation in the soil energy balance beneath a row-crop canopy. Agr. For. Meteorol. 63:7392.

Hancock, J.F., K. Haghighi, S.L. Krebs, J.A. Flore, and A.D. Draper. 1992. Photosynthetic heat stability in highbush blueberries and the possibility of genetic improvement. HortScience 27:1111-1112.

Kim, S.J., D.J. Yu, T.-C. Kim, and H.J. Lee. 2011 Growth and photosynthetic characteristics of blueberry (Vaccinium corymbosum cv. Bluecrop) under various shade levels. Sci. Hort. 129:486-492.

Kjelgren, R. 1994. Growth and water relations of Kentucky coffee tree in protective shelters during establishment. HortScience 29:777780 .

Kjelgren, R., D.T. Montague, and L.A. Rupp. 1997. Establishment of treeshelters II: Effect of shelter color on gas exchange and hardiness. HortScience 32:1284-1287.

Klassen, S. and B. Bugbee. 2005. Shortwave radiation. In: Hatfield, J.L. and J.M. Baker (eds.). Micrometeorology in agricultural systems. Agronomy Monograph 47. ASA-CSSASSSA, Madison, WI.

Laliberté, E., A. Bouchard, and A. Cogliastro. 2008. Optimizing hardwood reforestation in old fields: The effects of treeshelters and environmental factors on tree seedling growth and physiology. Restor. Ecol. 16:270-280.

Mayhead, G.J. and I.R. Boothman. 1997. The effect of treeshelter height on the early growth of sessile oak [Quercus petraea (Matt.) Liebl.]. Forestry 70:151-155.

Moon, J.W., J.A. Flore, and J.F. Hancock, Jr. 1987. A comparison of carbon and water vapor gas exchange characteristics between a diploid and highbush blueberry. J. Amer. Hort. Sci. 112:134-138.

Munnell, J.A. 2003. Determining the microenvironmental factors of grow tubes that affect grapevine (Vitis vinifera) growth and development. MS thesis, Wash. State Univ., Pullman, WA.

Murray, F.W. 1967. On the computation of saturation vapour pressure. J. Appl. Meteorol. 6:203204.

Oliet, J.A. and D.F. Jacobs. 2007. Microclimatic conditions and plant morpho-physiological development within a tree shelter environment during establishment of Quercus ilex seedlings. Agr. For. Meteorol. 144:58-72.

Rho, H., D.J. Yu, S.J. Kim, and H.J. Lee. 2012. Limitation factors for photosynthesis in 'Bluecrop' highbush blueberry (Vaccinium corymbosum) leaves in response to moderate water stress. J. Plant Biol. 55:450-457.

Sharew, H. and A. Hairston-Strang. 2005. A comparison of seedling growth and light transmission among tree shelters. North. J. Appl. For. 22:102-110.

Strik, C., C. Brun, M. Ahmedullah, A. Antonelli, L. Askham, D. Barney, P. Bristow, G. Fisher, J. Hart, D. Havens, R. Ingham, D. Kaufman, R. Penhallegon, J. Pscheidt, B. Scheer, C. Shanks, and R. William. 1993. Highbush blueberry production. Ore. State. Univ. Ext. Serv. Pub. PNW 215.

Swistock, B.R., K.A. Mecum, and W.E. Sharpe. 1999. Summer temperatures inside ventilated and unventilated brown plastic treeshelters in Pennsylvania. North. J. Appl. For. 16:7-10.

Tarara, J.M. and J.M. Ham. 1999. Measuring sensible heat flux in plastic mulch culture with aerodynamic conductance sensors. Agr. For. Meteorol. 95:1-13.

Tuley, G. 1983. Shelters improve the growth of young trees in the forest. Qrtly. J. For. 77:7787.

Tuley, G. 1985. The growth of young oak trees in shelters. Forestry 58:181-195.

U.S. Bureau of Reclamation. AgriMet. 2013. 17 Sept. 2013. <http://www.usbr.gov/pn/agrimet/ webarcread.html>.

Usowicz, B., J. Lipiec, J.B. Usowicz, and W. Marczewski. 2013. Effects of aggregate size on soil thermal conductivity: Comparison of measured and model-predicted data. Intl J. Heat Mass Transfer. 57:536-541. 